\title{
A mass spectrometric strategy for absolute quantification of Plasmodium falciparum proteins of low abundance
}

\author{
Paul M Southworth ${ }^{1,2}$, John E Hyde ${ }^{1}$ and Paul FG Sims ${ }^{1 *}$
}

\begin{abstract}
Selected reaction monitoring mass spectrometry has been combined with the use of an isotopically labelled synthetic protein, made up of proteotypic tryptic peptides selected from parasite proteins of interest. This allows, for the first time, absolute quantification of proteins from Plasmodium falciparum. This methodology is demonstrated to be of sufficient sensitivity to quantify, even within whole cell extracts, proteins of low abundance from the folate pathway as well as more abundant "housekeeping" proteins.
\end{abstract}

Keywords: Absolute quantification of proteins, enzymes of folate metabolism, heavy isotope labelling, malaria parasites, QconCAT

\section{Background}

Human malaria caused by Plasmodium falciparum is a major global health burden, killing around 1 million people every year [1]. Africa bears the greatest proportion of this burden, with over three-quarters of deaths occurring in African children, accounting for nearly a fifth of all child deaths in sub-Saharan Africa [2]. With the sequencing of the genome [3], as well as great advances in mass spectrometry (MS), characterization of the P. falciparum proteome is now technically possible. Information obtained using these techniques should be valuable in informing our future understanding of parasite/human interactions, disease progression and the selection of novel drug targets.

One important recent advance in MS is the development of so-called selected reaction monitoring (SRM). This is an analysis method used in triple quadrupole mass spectrometers. The first quadrupole acts as a mass filter, allowing through only ions of selected mass/charge ratios before they are fragmented, using the second quadrupole as a collision cell. The final quadrupole then acts as a mass filter of resulting fragment ions in a similar way to the first quadrupole, allowing through only fragment ions of a particular, selected mass [4]. Since different peptides

\footnotetext{
* Correspondence: paul.sims@manchester.ac.uk

${ }^{1}$ Manchester Interdisciplinary Biocentre, Faculty of Life Sciences, University of Manchester, 131 Princess Street, Manchester M1 7DN, UK

Full list of author information is available at the end of the article
}

of the same mass would be expected to show different fragmentation patterns, this method provides an extra degree of certainty of protein identification compared to MS of the peptides alone.

Further to these advances, recent work from this laboratory [5] has demonstrated that a form of 'soft' extraction of erythrocytic-stage $P$. falciparum parasites can resolve the issue of haemoglobin-derived products, which previously caused great hindrance in downstream methods of protein analysis. In addition, this work demonstrated the utility of the OFFGELTM (Agilent, UK) isoelectric fractionation system in separating whole $P$. falciparum proteins, rather than tryptic peptides, according to their pI. This fractionation is vitally important in the identification of proteins of low abundance, such as those of the folate and many other metabolic pathways, due to the complexity of the proteome. It is estimated that even in the most comprehensive proteomic studies of the P. falciparum lifecycle to date, only $\sim 46 \%$ of the predicted gene products were detected [6,7].

As well as identifying proteins of interest by fractionation followed by mass spectrometry, quantification of these proteins is also highly valuable in understanding the dynamics of biological systems. It has been shown a number of times that the expression of a particular gene as measured by mRNA quantification does not necessarily correlate with the level of protein within the cell [8-11].
C Biomed Central

(c) 2011 Southworth et al; licensee BioMed Central Ltd. This is an Open Access article distributed under the terms of the Creative Commons Attribution License (http://creativecommons.org/licenses/by/2.0), which permits unrestricted use, distribution, and reproduction in any medium, provided the original work is properly cited. 
Moreover, it is known that the P. falciparum proteome contains many unstructured proteins that can experience rapid degradation at both mRNA and protein levels $[12,13]$. In addition, the nature and degree of post-translational modifications, which can determine a number of protein properties including function, localization and activity, can only be analysed at the protein level.

Quantitative proteomics of the P. falciparum parasite is a field still in its infancy. In 2004, relative quantification was performed in this laboratory using a SILAC (stableisotope labelling of amino acids in cell culture) -based method [11]. While a significant step forward for plasmodial proteomics, this study necessarily focused on proteins of high abundance to establish proof of principle. Since then, other significant studies have been undertaken to assess plasmodial proteins in a quantitative manner $[14,15]$, but again, these studies determined only relative quantification.

In order to truly understand a biological system, we must aspire to absolute quantification of proteins across their entire dynamic range. By doing this, data from different studies and different laboratories can be more easily compared and proteomic, transcriptomic and metabolomic data can be more meaningfully correlated. One potential method for absolute protein quantification is the use of a heterologously expressed so-called QconCAT protein [16].

In this method, proteotypic tryptic peptides from proteins of interest, 'Q-peptides', are chosen. A number of these peptides are then expressed together from an artificial gene to produce a concatenated protein containing many different Q-peptides. Thus, when the QconCAT protein is digested using trypsin, peptides representing a number of proteins of interest are produced in equal molar amounts. If such QconCAT proteins are expressed, from Escherichia coli, in a labelled form using stable-isotope labelling, they can then be introduced, in a known amount, into biological samples prior to tryptic digestion and mass spectrometry. The resulting 'heavy' peaks on mass spectra, derived from the Q-peptides can be compared with the corresponding 'light' peaks, obtained concurrently from the native peptides, allowing accurate, absolute quantification. Producing a labelled QconCAT, rather than a labelled form of an entire native protein, allows several proteins to be efficiently quantified in the same experiment.

Here a QconCAT-based method, combined with SRM mass spectrometry, is described for the absolute quantification of proteins of low abundance in erythrocytic-stage P. falciparum.

\section{Methods}

\section{Plasmodium falciparum culture}

Plasmodium falciparum $\mathrm{K} 1$ parasites were grown in washed $\mathrm{O}+$ erythrocytes in RPMI 1640 medium
(Invitrogen, UK) as previously described [11,17]. The medium was supplemented with $0.5 \%$ bovine serum albumin, $5 \mu \mathrm{g} \cdot \mathrm{ml}^{-1}$ hypoxanthine and $50 \mu \mathrm{g} \cdot \mathrm{ml}^{-1}$ gentamicin sulphate (all Sigma Aldrich).

\section{Extraction of parasites}

Plasmodium falciparum parasites were freed from infected erythrocytes by lysis in $0.05 \%$ saponin in phosphate-buffered saline (PBS) for $5 \mathrm{~min}$. at $4^{\circ} \mathrm{C}$. This suspension was subsequently centrifuged at $800 \mathrm{~g}$ for $5 \mathrm{~min}$. at $4^{\circ} \mathrm{C}$. The resulting parasite pellets were washed in ice-cold PBS and spun at $1,000 \mathrm{~g}$ for $5 \mathrm{~min}$. This washing process was repeated at least twice more, until contaminating blood cell lysis products were no longer apparent in the PBS. The subsequent pellet was weighed and, if not being used immediately, snap-frozen in liquid nitrogen before storage at $-80^{\circ} \mathrm{C}$.

\section{Extraction of Plasmodium falciparum proteins}

Proteins were extracted from P. falciparum samples using the freeze-thaw method previously described [5]. For every $100 \mu \mathrm{g}$ of parasite pellet, $2.5 \mathrm{ml}$ of de-ionized water and $5 \mu \mathrm{l}$ of protease inhibitor cocktail (Sigma Protease Inhibitor Cocktail, P8340) was added and the pellet re-suspended. This suspension was frozen in liquid nitrogen for 5 min., thawed in a $37^{\circ} \mathrm{C}$ water bath and vortexed for $30 \mathrm{sec}$. at room temperature. This freeze-thaw cycle was subsequently repeated four times to ensure maximum protein extraction. The insoluble material was wholly removed by centrifugation three times at $16,000 \mathrm{~g}$ for $20 \mathrm{~min}$. at $4^{\circ} \mathrm{C}$. The soluble proteins thus extracted were precipitated by the addition of five volumes of acetone to the solution followed by incubation at $-20^{\circ} \mathrm{C}$ overnight. The resulting suspension was subsequently centrifuged at $12,000 \mathrm{~g}$ for $20 \mathrm{~min}$. at $4^{\circ} \mathrm{C}$ and the protein pellet air-dried.

\section{Design of PfQconCAT1}

Twelve $P$. falciparum proteins were chosen to be represented in the PfQconCAT1 protein. These included six enzymes of folate metabolism: GTP cyclohydrolase I (GTPCH), pyruvoyltetrahydropterin synthase III (PTPS), hydroxymethyldihydropterin pyrophosphokinase-dihydropteroate synthase (HPPK-DHPS), dihydrofolate synthasefolylpolyglutamate synthase (DHFS-FPGS), dihydrofolate reductase-thymidylate synthase (DHFR-TS) and serine hydroxymethyltransferase (SHMT). All of these proteins are known to be of a low abundance $[5,18]$. In order to represent some proteins of higher abundance and thus provide a context for the abundance figures sought, the following proteins were also represented: adenosine deaminase, disulphide isomerase, eukaryotic initiation factor $5 \alpha$ $(\mathrm{eIF} 5 \alpha)$, lactate dehydrogenase (LDH), plasmepsin I and pyruvate kinase. Each protein was represented by four 
peptides in the QconCAT protein. Two calibration peptides were also included (see Additional file 1 - Annotated amino acid sequence of PfQconCAT1).

For those folate pathway proteins identified previously by mass spectrometry in our laboratory (PTPS, HPPKDHPS, DHFR-TS and SHMT), peptides were chosen which had previously been seen in the mass spectra [5]. For those proteins in which more than four different peptides had been seen, the four seen with highest intensity were chosen. For all other proteins, theoretical peptides were chosen using Peptide Predictor Version 2 software. This is a locally written derivative of the widely available Peptide Sieve software (Seattle Proteome Center). The software allows screening of peptides in proteins for high 'flyability' and low probability of missed cleavages in trypsin digestion (for example, ensuring that an acidic aminoacid residue is not present two places after a lysine or arginine residue). This program was first run using those proteins already identified in mass spectra. The predictions made by the software were found to be highly concordant with the visibility of peptides in experimental results.

In the QconCAT protein, no two peptides representing the same protein were placed consecutively. This was to ensure that any missed cleavages did not eliminate the ability for quantification of two peptides from the same protein. A process of trial and error was then used placing the 74 peptides in various configurations and assessing with Peptide Predictor to ensure that missed tryptic cleavages remained a low probability. A sacrificial $\mathrm{N}$-terminus and His-tagged C-terminus (to facilitate purification) were then added and the sequence was sent to PolyQuant (http://www.polyquant.com) for codon optimization and gene synthesis. The amino-acid sequence is shown in annotated form (Additional file 1 - Annotated amino acid sequence of PfQconCAT1).

\section{Synthesis of labelled PfQconCAT1 protein}

Rosetta $^{\mathrm{TM}} 2$ (DE3) pLysS cells were transformed with the sequence-verified, artificial $P F Q \operatorname{con} C A T 1$ gene received from PolyQuant in the pET21 vector. These cells were grown overnight on LB agar and used to inoculate $500 \mathrm{ml}$ of PA-5052 medium [19] supplemented with both ${ }^{13} \mathrm{C}$ labelled arginine and ${ }^{13} \mathrm{C}$-labelled lysine $\left(0.2 \mathrm{mg} \mathrm{ml}^{-1}\right.$ each). PA-5052 is made as follows: $50 \mathrm{mM} \mathrm{Na}_{2} \mathrm{HPO}_{4}$, $50 \mathrm{mM} \mathrm{KH} \mathrm{PO}_{4}, 25 \mathrm{mM}\left(\mathrm{NH}_{4}\right)_{2} \mathrm{SO}_{4}, 0.5 \%$ (v/v) glycerol, $0.05 \%(\mathrm{w} / \mathrm{v})$ glucose, $0.2 \%(\mathrm{w} / \mathrm{v}) \alpha$-lactose monohydrate, 2 $\mathrm{mM} \mathrm{MgSO}_{4}, 50 \mathrm{mM} \mathrm{FeCl}_{3}, 20 \mu \mathrm{M} \mathrm{CaCl}_{2}, 10 \mu \mathrm{M} \mathrm{MnCl}_{2}$, $10 \mu \mathrm{M} \mathrm{ZnSO}_{4}, 2 \mu \mathrm{M} \mathrm{CoCl}_{2}, 2 \mu \mathrm{M} \mathrm{CuCl}_{2}, 2 \mu \mathrm{M} \mathrm{NiCl}_{2}$, $2 \mu \mathrm{M} \mathrm{Na}_{2} \mathrm{MoO}_{4}, 2 \mu \mathrm{M} \mathrm{Na}_{2} \mathrm{SeO}_{3}, 2 \mu \mathrm{M} \mathrm{H}_{3} \mathrm{BO}_{3}$ and $0.2 \mathrm{mg} \cdot \mathrm{ml}^{-1}$ each of the following amino acids: alanine, aspartate, glutamine, glycine, isoleucine, leucine, methionine, proline, serine, threonine, tryptophan, valine, phenylalanine, monosodium glutamate, asparagine monohydrate and histidine monochloride. The cells were then grown in this auto-induction medium over two nights at $37^{\circ} \mathrm{C}$ with agitation until the $\mathrm{OD}_{600}$ plateaued (usually an $\mathrm{OD}_{600}$ of between 6 and 12). The cells were then harvested by centrifugation for $20 \mathrm{~min}$. at $4,000 \mathrm{~g}$ at $4^{\circ} \mathrm{C}$.

These cells were subsequently processed as described previously [20]. The cells were lysed using Bugbuster (Novagen) according to the manufacturer's guidelines. The resulting suspension was centrifuged at $16,000 \mathrm{~g}$ for $20 \mathrm{~min}$. at $4^{\circ} \mathrm{C}$ and the supernatant discarded. The pellet was re-suspended in the same amount of Bugbuster again by Pasteur pipetting. Lysozyme $\left(250 \mathrm{ml}\right.$ of $10 \mathrm{mg} \cdot \mathrm{ml}^{-1}$ in Bugbuster) was added and mixed by gentle vortexing. This was incubated at room temperature for $5 \mathrm{~min}$. followed by centrifuging at $15,000 \mathrm{~g}$ for $15 \mathrm{~min}$. at $4^{\circ} \mathrm{C}$. The resulting supernatant was discarded. This pellet was re-suspended in $20 \mathrm{ml}$ of a $1 / 10$ dilution of Bugbuster in de-ionized water then centrifuged again at $15,000 \mathrm{~g}$ for $15 \mathrm{~min}$. at $4^{\circ} \mathrm{C}$. This washing in 1/10 Bugbuster was repeated twice more to produce a pellet of washed inclusion bodies.

The inclusion bodies were re-suspended in $20 \mathrm{ml}$ of column buffer $\left(20 \mathrm{mM} \mathrm{Na}_{2} \mathrm{HPO}_{4} / \mathrm{NaH}_{2} \mathrm{PO}_{4} \mathrm{pH} 7.4,500 \mathrm{mM}\right.$ $\mathrm{NaCl}, 10 \mathrm{mM}$ imidazole, $6 \mathrm{M}$ guanidinium chloride [all Sigma Aldrich]) and were subsequently centrifuged at $8,000 \mathrm{rpm}$ for $5 \mathrm{~min}$. at room temperature. The supernatant was transferred to a fresh tube and the pellet discarded. A $1 \mathrm{ml}$ HiTrap Chelating HP column (GE Healthcare) was equilibrated with column buffer using an AKTA purification system. The previously prepared crude extract was then applied to the column at a flow rate of $0.25 \mathrm{ml} . \mathrm{min}^{-1}$ and the column was washed with wash buffer $\left(20 \mathrm{mM} \mathrm{Na}_{2} \mathrm{HPO}_{4} / \mathrm{NaH}_{2} \mathrm{PO}_{4} \mathrm{pH} 7.4,500 \mathrm{mM} \mathrm{NaCl}\right.$, $20 \mathrm{mM}$ imidazole, $6 \mathrm{M}$ guanidinium chloride) until no protein could be seen eluting from the column on the UV absorbance output. The bound protein was then eluted from the column by switching from wash buffer to elution buffer $\left(20 \mathrm{mM} \mathrm{Na} 2 \mathrm{HPO}_{4} / \mathrm{NaH}_{2} \mathrm{PO}_{4} \mathrm{pH} 7.4,500 \mathrm{mM}\right.$ $\mathrm{NaCl}, 500 \mathrm{mM}$ imidazole, $6 \mathrm{M}$ guanidinium chloride) on a $20 \mathrm{~min}$. linear gradient. The resulting solution was dialysed into $6 \mathrm{M}$ urea overnight. Dialysing into lower concentrations was found to result in precipitation of the protein, which would subsequently prove difficult to resolubilize. Quantification of the protein was performed using a 2D Quant kit (GE Healthcare).

\section{Selected reaction monitoring mass spectrometry analysis} Acetone-precipitated protein obtained from P. falciparum samples was trypsin-digested using an Amicon Ultra $0.5 \mathrm{ml} 10 \mathrm{kDa}$ molecular weight cut-off centrifugal filter unit (Millipore). The dried protein sample was first taken up in $15.5 \mu$ ldigestion buffer $\left(50 \mathrm{mM} \mathrm{NH} \mathrm{HCO}_{3}, 20 \mathrm{mM}\right.$ $\mathrm{CaCl}_{2}, 2 \mathrm{M}$ Urea) and applied to the upper chamber of an Amicon filter. An appropriate, known amount of labelled PfQconCAT1 protein was added $(1 \mathrm{pmol}$ per $100 \mu \mathrm{g}$ 
plasmodial extract) followed by $2.5 \mu \mathrm{l}$ of $10 \mathrm{mM}$ DTT and the whole incubated for $20 \mathrm{~min}$. at room temperature. Subsequently, $2 \mu \mathrm{l}$ of $30 \mathrm{mM}$ iodoacetamide was added and incubated for a further $20 \mathrm{~min}$. at room temperature. A further $200 \mu \mathrm{l}$ of digestion buffer was then added and the column was spun at $14,000 \mathrm{~g}$ for $15 \mathrm{~min}$. The filtrate was then discarded and the filter chamber transferred to a fresh tube. Proteomics grade trypsin $\left(0.1 \mathrm{mg} \cdot \mathrm{ml}^{-1}\right.$, Sigma Aldrich) in $50 \mathrm{mM} \mathrm{NH}_{4} \mathrm{HCO}_{3}$ was then added to give $1 \mu \mathrm{g}$ trypsin for every $50 \mu \mathrm{g}$ protein to be digested and the whole was incubated overnight at $37^{\circ} \mathrm{C}$. Formic acid $(1 \mu \mathrm{l})$ was added to stop the reaction followed by $200 \mu \mathrm{l}$ of $50 \mathrm{mM} \mathrm{NH} \mathrm{HCO}_{3}$. The column was centrifuged at $14,000 \mathrm{~g}$ for $15 \mathrm{~min}$. and the filter was discarded. The filtrate was then dried in a vacuum centrifuge and re-suspended in $10 \%$ acetonitrile, $0.1 \%$ formic acid for analysis by mass spectrometry.

This analyte was loaded onto a Symmetry ${ }^{\circledR}$ C18 HPLC trapping column of $20 \mathrm{~mm}$ length and an internal diameter (ID) of $180 \mu \mathrm{m}$ (Waters) coupled to a BEH130 C18 HPLC analytical column of $15 \mathrm{~cm}$ length and an ID of $75 \mu \mathrm{m}$ (Waters nanoACQUITYTM UPLC). The peptides were eluted from these columns using a 3-40\% gradient of $100 \%$ acetonitrile with water (both containing $0.1 \%$ formic acid) at a flow rate of $300 \mathrm{nl} . \mathrm{min}^{-1}$. The peptides were eluted into a Xevo TQMS (Waters) mass spectrometer (ionization through electrospray ionization and mass analysis through tandem quadrupoles) using an SRM transition list (see Additional file 2 - SRM Transition List). Data were acquired using MassLynx software (Waters).

\section{Tandem mass spectrometry analysis}

Trypsin-digested analyte was loaded onto a Symmetry ${ }^{\circledR}$ C18 HPLC trapping column of $20 \mathrm{~mm}$ length and an internal diameter (ID) of $180 \mu \mathrm{m}$ (Waters) coupled to a BEH130 C18 HPLC analytical column of $15 \mathrm{~cm}$ length and an ID of $75 \mu \mathrm{m}$ (Waters nanoACQUITYTM UPLC). The peptides were eluted from these columns using a 3$40 \%$ gradient of $100 \%$ acetonitrile with water (both containing $0.1 \%$ formic acid) at a flow rate of $300 \mathrm{nl}_{\mathrm{min}}{ }^{-1}$. The peptides were eluted into a Synapt G1 High Definition mass spectrometer (Waters; ionization through electrospray and mass analysis through quadrupole time of flight) run in $\mathrm{MS}^{\mathrm{E}}$ mode. Data were acquired and analysed using MassLynx (v4.1) and Protein Lynx Global Server (v2,4) software packages respectively (Waters).

\section{Results}

\section{Development of PfQconCAT1 SRM transition list}

Initially, an SRM transition list was produced for the PfQconCAT1 protein using Pinpoint software (Thermo Finnigan) to predict what fragment ions might be seen from the second round of MS (see Additional file 2 - SRM Transition List). This analysis also recognized the value of choosing singly charged fragment ions whose $\mathrm{m} / \mathrm{z}$ was greater than that of their doubly charged parent ions, thus helping to minimize background intensity that might be generated from the latter during the SRM analyses. However, to be sure that useful fragment ions would indeed be produced experimentally, purified heterologously expressed $P f Q$ conCAT1 was trypsin digested and run in $\mathrm{MS}^{\mathrm{E}}$ mode on a Synapt G1 QToF mass spectrometer. The list of precursor and fragment ions seen (see Additional file 3 - Precursor and fragment ions found through trypsin digestion and Synapt QToF mass spectrometry of heterologously expressed ${ }^{13} \mathrm{C}$-labelled PfQconCAT1), which includes those derived from all of the targeted proteins other than plasmepsin I, is significantly different to that prepared using the predictive software (see Additional file 2 - SRM Transition List). Thus, approximately $77 \%$ of predicted fragment ions were not seen experimentally and $37 \%$ of ions seen experimentally were not predicted. This discordance between predictions of which theoretical peptides might be best chosen as proteotypic, particularly with respect to their detection in the mass spectrometer (selection of characteristic transitions) is notable. It illustrates the value, for future studies, of taking every effort to select peptides/transitions that have previously been experimentally demonstrated.

\section{Quantification of Plasmodium falciparum proteins}

Trypsin-digested $P$. falciparum protein $(2 \mu \mathrm{g})$ was loaded onto the Xevo TQ mass spectrometer and analysed using SRM as described above. Results from QconCAT-based quantification of proteins from two unsynchronized P. falciparum cultures are shown in Table 1 .

In order for quantification to be performed, both labelled and unlabelled forms of the peptides must be seen in mass spectra of the samples. This was the case for three of the peptides in both experiments (representing DHFR-TS, eIF5 $\alpha$ and SHMT) and for two additional peptides in one of the experiments (representing adenosine deaminase and disulphide isomerase). Extracted ion chromatograms of three transitions from both labelled and unlabelled forms of a peptide chosen as diagnostic for SHMT (SHMT-4) are shown in Figure 1. Additional file 4 - Extracted ion chromatograms from experimentally observed peptides - shows all of the transitions observed in the two independent experiments from which the data presented in Table 1 were derived. The fact that some peptides were seen in one experiment and not in the other may reflect differences in ion suppression effects in different complex mixtures of peptides. For those peptides seen in both experiments, a high degree of reproducibility was seen with similar abundance figures obtained for the same peptides in each experiment (standard error varied between $4.0 \%$ and $6.7 \%$ of the average). 
Table 1 Quantification of $P$. falciparum proteins from two unsynchronized erythrocytic-stage cultures

\begin{tabular}{|c|c|c|c|c|c|c|}
\hline Peptide & Fragment Ion Type & Calculated Native Level (Culture 1) & Peptide Average & Calculated Native Level (Culture 2) & Peptide Average & Average Between Samples \\
\hline \multirow[t]{3}{*}{ Adenosine Deaminase-1 } & y4 & 5.96 & $6.53(0.23)$ & - & - & - \\
\hline & y5 & 6.83 & & - & & \\
\hline & y6 & 6.79 & & - & & \\
\hline \multirow[t]{3}{*}{ Disulphide Isomerase-1 } & y5 & 9.54 & $16.47(2.83)$ & - & - & - \\
\hline & y6 & 20.11 & & - & & \\
\hline & y7 & 19.76 & & - & & \\
\hline \multirow[t]{3}{*}{ DHFR-TS-4 } & $y 7$ & 0.68 & $0.31(0.15)$ & 0.24 & $0.68(0.20)$ & $0.50(0.02)$ \\
\hline & y8 & 0.05 & & 1.09 & & \\
\hline & y10 & 0.21 & & 0.72 & & \\
\hline \multirow[t]{3}{*}{ elF5 $\alpha-3$} & y6 & 18.64 & $19.05(1.90)$ & 20.33 & $22.98(2.13)$ & $21.02(1.39)$ \\
\hline & y8 & 15.23 & & 28.20 & & \\
\hline & y9 & 23.27 & & 20.41 & & \\
\hline \multirow[t]{3}{*}{ SHMT-4 } & y5 & 0.48 & $0.87(0.31)$ & 0.69 & $0.99(0.29)$ & $0.93(0.04)$ \\
\hline & y6 & 0.49 & & 1.69 & & \\
\hline & y7 & 1.63 & & 0.58 & & \\
\hline
\end{tabular}

All figures are pmol per $100 \mu \mathrm{g}$ of $P$. falciparum protein and numbers in brackets represent standard errors. Adenosine Deaminase-1 and Disulphide Isomerase-1 were only detected in experiment 1. 
A
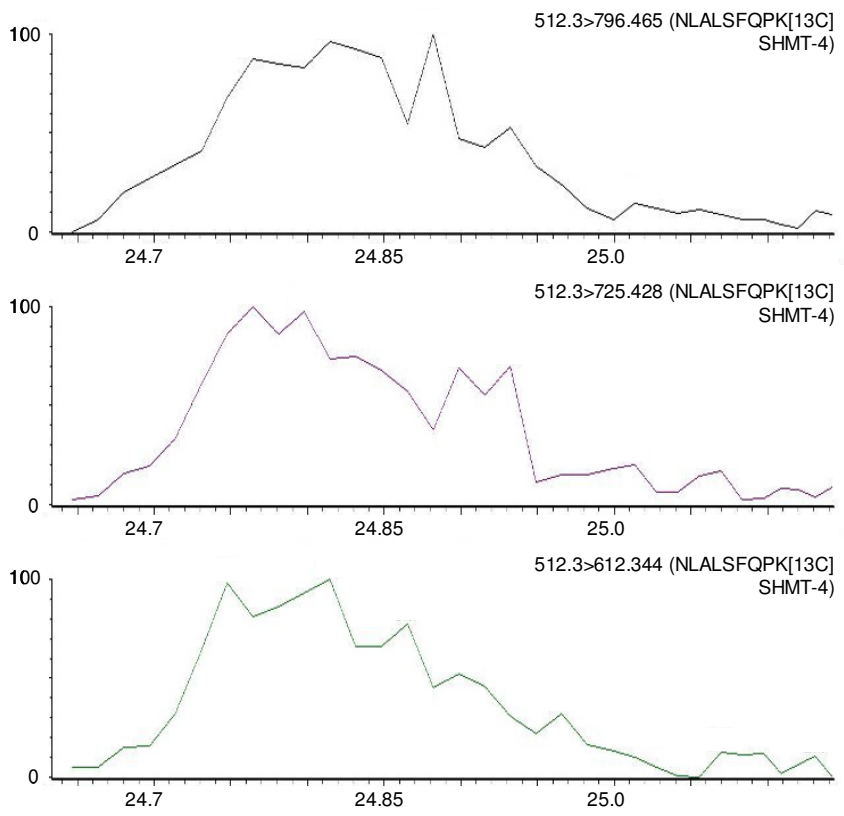

B
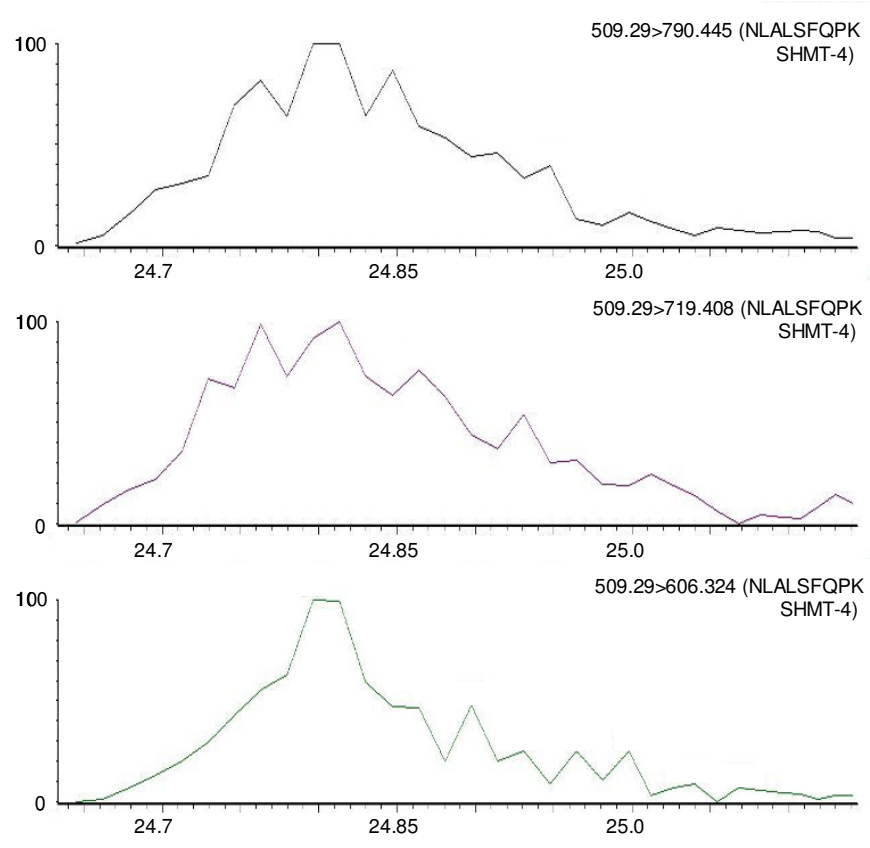

Figure 1 Extracted ion chromatograms of transitions derived from peptide SHMT-4. The ordinate represents the peak intensity (normalised to $100 \%$ ) and the abscissa the time within the elution gradient (minutes) that this intensity was detected. Panel A, transitions corresponding to the labelled version of this peptide; Panel B, transitions corresponding to the unlabelled version of this peptide. The relative area under each of the traces and the known amount of the standard (labelled) peptide added were used to calculate the amount of the unlabelled peptide and thus the amount of the equivalent protein present in the sample analyzed. 
Overall, abundance figures for the six peptides seen reflect what would be expected, with enzymes of the folate pathway of substantially lower abundance than the other enzymes. Furthermore, the two enzymes identified from the folate pathway are the two hypothesized to be the two most abundant within this pathway based on previous transcriptomic data [11]. In that study, the SHMT transcript was also found to be more abundant than that of DHFR-TS, a result also reflected in these proteomic results. Another notable outcome from these experiments is that in using a mass spectrometric method as sensitive as SRM, proteins of very low abundance can be seen without any fractionation of such a complex proteome. Fractionation using methods such as OFFGEL ${ }^{\mathrm{TM}}$ isoelectric fractionation have recently been demonstrated to have the potential to mine deep into the proteome, with four of the six folate enzymes being identified using this method [5]. Using the SRM method described in this paper in combination with OFFGEL ${ }^{\mathrm{TM}}$, a fifth folate enzyme (GTPCH) has also been identified (data not shown) showing the potential of this combined approach to mine and quantify a large portion of the $P$. falciparum proteome.

\section{Conclusions}

Combining the use of a heavy-labelled, custom-designed QconCAT protein with SRM mass spectrometry has allowed the absolute quantification of even low abundance proteins from the folate metabolic pathway within unfractionated cell extracts. This method can easily be targeted to any plasmodial protein, for the first time offering a direct route to absolute quantification of malarial proteins. Furthermore, with the ability to represent a dozen or more proteins of interest in one labelled artificial protein, there is great potential for this approach to provide a relatively high-throughput application to absolutely quantify plasmodial proteomics. Such quantification will be a prerequisite for successful application of systems biology techniques to the in-depth analysis of parasite biochemistry.

\section{Additional material}

Additional file 1: Annotated amino acid sequence of PfQconCAT1.
Additional file 2: SRM Transition List.
Additional file 3: Precursor and fragment ions found through
trypsin digestion and Synapt QToF mass spectrometry of
heterologously expressed ${ }^{13}$ C-labelled PfQconCAT1.
Additional file 4: Extracted ion chromatograms from experimentally
observed peptides.

List of abbreviations

DHFR-TS: dihydrofolate reductase-thymidylate synthase; DHFS-FPGS: dihydrofolate synthase-folylpolyglutamate synthase; elF5a: eukaryotic initiation factor 5a; GTPCH: GTP cyclohydrolase I; HPPK-DHPS: hydroxymethyldihydropterin pyrophosphokinase-dihydropteroate synthase; LDH: lactate dehydrogenase; MS: mass spectrometry; PTPS: pyruvoyltetrahydropterin synthase III; SHMT: serine hydroxymethyltransferase; SRM: selected reaction monitoring.

\section{Acknowledgements}

The Wellcome Trust, UK (grant no. 073896) and BBSRC, UK (studentship to PMS) are thanked for their financial support and Drs Ronan O'Cualain and Stephen Holman for assistance with mass spectrometry.

\section{Author details}

${ }^{1}$ Manchester Interdisciplinary Biocentre, Faculty of Life Sciences, University of Manchester, 131 Princess Street, Manchester M1 7DN, UK. ²aboratory of Malaria Immunology and Vaccinology, National Institute of Allergy and Infectious Disease, National Institutes of Health, 12735 Twinbrook Parkway, Rockville MD 20814, USA.

\section{Authors' contributions}

PMS carried out all the experimental work and drafted the manuscript. JEH and PFGS conceived the study and revised the manuscript. All authors were involved in experimental design, data interpretation and analysis and have read and approved the final manuscript.

\section{Competing interests}

The authors declare that they have no competing interests.

Received: 17 August 2011 Accepted: 25 October 2011

Published: 25 October 2011

\section{References}

1. Greenwood BM, Fidock DA, Kyle DE, Kappe SHI, Alonso PL, Collins FH, Duffy PE: Malaria: progress, perils, and prospects for eradication. J Clin Invest 2008, 118:1266-1276.

2. Rowe AK, Rowe SY, Snow RW, Korenromp EL, Schellenberg JRA, Stein C, Nahlen BL, Bryce J, Black RE, Steketee RW: The burden of malaria mortality among African children in the year 2000. Int J Epidemiol 2006 35:691-704.

3. Gardner MJ, Hall N, Fung E, White O, Berriman M, Hyman RW, Carlton JM, Pain A, Nelson KE, Bowman S, Paulsen IT, James K, Eisen JA, Rutherford K, Salzberg SL, Craig A, Kyes S, Chan MS, Nene V, Shallom SJ, Suh B, Peterson J, Angiuoli S, Pertea M, Allen J, Selengut J, Haft D, Mather MW, Vaidya $A B$, Martin DMA, et al: Genome sequence of the human malaria parasite Plasmodium falciparum. Nature 2002, 419:498-511.

4. Ong SE, Mann M: Mass spectrometry-based proteomics turns quantitative. Nat Chem Biol 2005, 1:252-262.

5. O'Cualain RDM, Hyde JE, Sims PFG: A protein-centric approach for the identification of folate enzymes from the malarial parasite, Plasmodium falciparum, using OFFGEL ${ }^{\mathrm{TM}}$ solution-based isoelectric focussing and mass spectrometry. Malar J 2010, 9:286.

6. Florens L, Washburn MP, Raine JD, Anthony RM, Grainger M, Haynes JD, Moch JK, Muster N, Sacci JB, Tabb DL, Witney AA, Wolters D, Wu YM, Gardner MJ, Holder AA, Sinden RE, Yates JR, Carucci DJ: A proteomic view of the Plasmodium falciparum life cycle. Nature 2002, 419:520-526.

7. Lasonder E, Ishihama Y, Andersen JS, Vermunt AMW, Pain A, Sauerwein RW, Eling WMC, Hall N, Waters AP, Stunnenberg HG, Mann M: Analysis of the Plasmodium falciparum proteome by high-accuracy mass spectrometry. Nature 2002, 419:537-542.

8. Anderson L, Seilhamer J: A comparison of selected mRNA and protein abundances in human liver. Electrophoresis 1997, 18:533-537.

9. Ideker T, Thorsson V, Ranish JA, Christmas R, Buhler J, Eng JK, Bumgarner R, Goodlett DR, Aebersold R, Hood L: Integrated genomic and proteomic analyses of a systematically perturbed metabolic network. Science 2001, 292:929-934.

10. Le Naour F, Hohenkirk L, Grolleau A, Misek DE, Lescure P, Geiger JD, Hanash S, Beretta L: Profiling changes in gene expression during differentiation and maturation of monocyte-derived dendritic cells using both oligonucleotide microarrays and proteomics. J Biol Chem 2001, 276:17920-17931.

11. Nirmalan N, Sims PFG, Hyde JE: Quantitative proteomics of the human malaria parasite Plasmodium falciparum and its application to studies of development and inhibition. Mol Microbiol 2004, 52:1187-1199. 
12. Feng ZP, Zhang XZ, Han PF, Arora N, Anders RF, Norton RS: Abundance of intrinsically unstructured proteins in $P$. falciparum and other apicomplexan parasite proteomes. Mol Biocheml Parasitol 2006, 150:256-267.

13. Gsponer J, Futschik ME, Teichmann SA, Babu MM: Tight regulation of unstructured proteins: from transcript synthesis to protein degradation. Science 2008, 322:1365-1368.

14. Foth BJ, Zhang N, Mok S, Preiser PR, Bozdech Z: Quantitative protein expression profiling reveals extensive post-transcriptional regulation and post-translational modifications in schizont-stage malaria parasites. Genome Biol 2008, 9:R177.

15. Prieto JH, Koncarevic S, Park SK, Yates J, Becker K: Large-scale differential proteome analysis in Plasmodium falciparum under drug treatment. PLOS ONE 2008, 3:e4098.

16. Beynon RJ, Doherty MK, Pratt JM, Gaskell SJ: Multiplexed absolute quantification in proteomics using artificial QCAT proteins of concatenated signature peptides. Nat Methods 2005, 2:587-589.

17. Read M, Hyde JE: Simple in vitro cultivation of the malaria parasite Plasmodium falciparum (erythrocytic stages) suitable for large-scale preparations. In Protocols in Molecular Parasitology. Volume 21. Edited by: Hyde JE Totowa. New Jersey: Humana Press; 1993:43-55, Methods in Molecular Biology.

18. Nirmalan N, Flett F, Skinner T, Hyde JE, Sims PFG: Microscale solution isoelectric focusing as an effective strategy enabling containment of hemeoglobin-derived products for high-resolution gel-based analysis of the Plasmodium falciparum proteome. J Proteome Res 2007, 6:3780-3787.

19. Studier FW: Protein production by auto-induction in high-density shaking cultures. Protein Expr Purif 2005, 41:207-234.

20. Pratt JM, Simpson DM, Doherty MK, Rivers J, Gaskell SJ, Beynon RJ: Multiplexed absolute quantification for proteomics using concatenated signature peptides encoded by QconCAT genes. Nat Protocols 2006, 1:1029-1043.

doi:10.1186/1475-2875-10-315

Cite this article as: Southworth et al:: A mass spectrometric strategy for absolute quantification of Plasmodium falciparum proteins of low abundance. Malaria Journal 2011 10:315.

\section{Submit your next manuscript to BioMed Central and take full advantage of:}

- Convenient online submission

- Thorough peer review

- No space constraints or color figure charges

- Immediate publication on acceptance

- Inclusion in PubMed, CAS, Scopus and Google Scholar

- Research which is freely available for redistribution

Submit your manuscript at www.biomedcentral.com/submit 